\title{
The current performance-linked and risk sharing agreement scene in the Spanish region of Catalonia
}

Josep Darbà1, Meritxell Ascanio²

${ }^{1}$ Universitat de Barcelona, Barcelona, Spain; 2 BCN Health Economics \& Outcomes Research S.L., Barcelona, Spain

Correspondence to:

Josep Darbà

Department of Economics. Universitat de Barcelona, Diagonal 696, 08034 Barcelona, Spain

Tel. +34 934020110/ + 34934021937

Fax +34934039082

E-mail darba@ub.edu

\begin{abstract}
Background: Traditional drug payment schemes in Catalonia are generally based on the negotiation of fixed prices; however, disadvantages arise in the case of innovative therapies. Risk sharing agreements distribute potential health and economic uncertainties and high prices on access across the interested parts.

Objectives: To identify, characterize and analyze current publicly available agreement reports signed by the Catalan Health Service and different pharmaceutical companies evaluating the current market access scene for new drugs in Catalonia.

Methods: A database of agreements implemented between 2013 and 2018 was developed by using publicly available data. Data analysis was performed in a descriptive way, presenting summaries in datasheets.

Results: A total of 7 managed entry agreements were analyzed. Two extensions regarding previous agreements were also taken into account. The main involved disease area is oncology (57\%) and the most common length is 1 year, whereas the longest is 3 years.
\end{abstract}


Conclusions: Managed entry agreements are gaining popularity and are viewed as positive schemes by stakeholders, payers and health services, leading to a general increase of accords during the last years. However, there are hardly any studies regarding the impact of RSA post-implementation, a field of great relevance regarding health policies.

\section{KEYWORDS}

Managed entry agreements; performance-linked reimbursement; risk sharing agreement; Catalonia; expenditure ceiling

\section{INTRODUCTION}

Traditional drug payment schemes in Catalonia regarding both public and private insurances are generally based on the negotiation of fixed prices according to the volume of patients that are suitable to obtain and benefit from the treatment. When this is the case, it is the buyer who withstands both the economical and health-related risk. It is an efficient procedure when comparing the studied drug to commercialized alternatives; however, disadvantages arise in the case of innovative therapies. These come in the form of drug effectiveness, safety, efficacy in comparison to alternative therapies, economic impact and costeffectiveness uncertainties, large budget impacts and the prospect of decreasing marginal benefits [1]. All these factors make it difficult to determine new drug price, discouraging market access for innovative drugs [2].

Risk sharing agreements (RSA) or managed entry agreements (MEA) distribute potential health and economic uncertainties and high prices on access across the interested parts, in this concrete case, the hospital and the pharmaceutical company [3]. An accepted breakdown of RSAs is financial and outcome based as first proposed by Adamski et al [4]. There is not one definite classification of these schemes, meaning different taxonomies classify models in different manners. The Catalan Health Service (CatSalut) differentiates agreements based on economic results and agreements based on clinical results. The latter is subcategorized into performance-linked reimbursements (PLR) and conditional reimbursements $[1,5]$. 
PLRs are also called performance-based risk sharing agreement, payment-by-response, payment-byperformance, outcomes-based agreements and patient access schemes according to the country or the publication [6].

The value drivers regarding these agreements can be perceived from both the payer's and the manufacturer's point of view. While payers are interested in cost reductions, an increase in pharmacy discount or reimbursement, reduced final risks and improved patient access; manufacturers are driven by an improved level of access, reduced uncertainties regarding long-term benefits and increased revenue [7].

Most RSAs are for oncology and other high priced products. This is not surprising since prices for oncology medicines have raised appreciably in recent years $[8,9]$ despite limited health gain with a number of them [10-12]. This situation can only get worse given the high number of cancer medicines in development and likely prices despite the fact that the costs of goods can be low for a number of them $[13,14]$.

Studies regarding MEA in regions such as Australia, Italy, Sweden, United States, United Kingdom, Belgium, the Netherlands, the Middle East, North Africa, Central and Eastern Europe are published [3,7,1520]. However, despite an increase in risk-sharing agreements interest in the EU and the subsequent inflation of publications [21], the only recent paper concerning MEA in Catalonia refers to a 2011 paymentby-results agreement regarding gefitinib (Iressa $\left.{ }^{\circledR}\right)$ and is based on data obtained from an interview [2]. The same report is mentioned in a European MEA review in a very non-exhaustive manner [22].

Therefore, there is an obvious need to update the available information regarding MEA in Catalonia. Herein we identify, source, characterize and analyze current publicly available agreement reports signed by the Catalan Health Service (CatSalut) and diverse pharmaceutical companies with the objective of evaluating the current market access scene for new drugs in Catalonia.

\section{METHODS}

A database of agreements implemented between 2013 and 2018 was developed using publicly available data obtained from the Catalan health department in July 2018. The agreements analysed were obtained from the CatSalut web page [23]. A total of $7 \mathrm{MEA}$ and 2 extensions regarding previous agreements were analyzed throughout the study. These MEA involved 9 pharmaceutical companies, 9 drugs and 8 different 
indications. A descriptive data analysis was performed, presenting summaries in datasheets and values in percentage form.

The following information was gleaned from the dossiers and was considered in the descriptive analysis: report date, agreement type, agreement length, drug name, active ingredient, pharmaceutical company, indication, inclusion criteria, exclusion criteria, time to response evaluation, response evaluation criteria, result evidence, patient classification by response, economic conditions, reimbursement and if the agreement has been extended.

\section{RESULTS}

In this study only two types of MEA were identified. They correspond to performance-linked reimbursement (PLR), defined as the return of a product or economic value according to the clinical outcomes of the treatment, and risk sharing agreements (RSA), specifying an explicit expenditure ceiling.

The earliest agreement analyzed was signed in 2013 [24]. It corresponds to a PLR agreement between the University Hospital of Bellvitge and a pharmaceutical company for the use of certolizumab pegol combined with methotrexate in the population with rheumatoid arthritis when the response to disease-modifying antirheumatic drugs (including methotrexate) has been inadequate. In this case, the hospital only paid for those patients included that the program reached an optimal clinical response in week 12 according to the clinical variables established in the agreement (Table 1). According to the contract, there was a previous PLR agreement between the pharmaceutical company and Hospital Clinic de Barcelona dated 5 November 2012 for the use of certolizumab pegol in the treatment of rheumatoid arthritis.

The first agreement extension analyzed was signed also in 2013 [25] and corresponds to a one-year prolongation of the convention singed in July 2011 between a pharmaceutical company, CatSalut and Catalan Institute of Oncology (ICO) (Table 2). It was agreed to administer tyrosine kinase protein inhibitors to patients with first-line metastatic non-small cell lung cancer, seen at any of the ICO centers.

In 2017, five PLR agreements and one extension were signed (Table 3). The first PLR was signed between a pharmaceutical company and CatSalut for the use of panitumumab in adult patients with metastatic colorectal carcinoma ( $\mathrm{mCRC}$ ) with non-mutated RAS (wild-type) in the first line in combination with 
FOLFOX (fluorouracil, leucovorin, oxaliplatin) [26]. In this case the hospitals only paid for those patients with no disease progression in week $12+/-1$ (Table S1). The second PLR involved a pharmaceutical company and CatSalut and agreed to use pembrolizumab in patients diagnosed with advanced melanoma (metastatic or unresectable) [27]. In this case, the reimbursement depended on the percentage of patients who interrupted the treatment during the first 4 cycles of the total number of patients included (Table S2). The third PLR agreement was signed between a pharmaceutical company and CatSalut for the use of fampridine for the improvement of gait in patients with multiple sclerosis with gait disability [28]. The hospitals paid only for those patients who maintained 3 months the improvement observed at two weeks according to the criteria established in the agreement (Table S3). The fourth PLR involved a pharmaceutical company and CatSalut, and agreed the use of pertuzumab in combination with trastuzumab in the neoadjuvant treatment of HER2 positive breast cancer [29]. The pharmaceutical company will only assume the full cost of pertuzumab used in the neoadjuvant treatment, in combination with trastuzumab and chemotherapy, of that proportion of patients that do not reach clinical response (patients with stable or progressive disease, according to RECIST criteria) (Table S4). The last PLR agreement was signed between a pharmaceutical company and CatSalut for the use of trametinib in combination with dabrafenib in the treatment of adult patients with unresectable or metastatic melanoma with BRAF V600 mutation [30]. In this case, the pharmaceutical company will assume the treatment cost for those patients considered nonresponders because of the suspension of treatment due to having experienced progression of the disease or unmanageable adverse effects with temporary interruption and / or dose reduction, causing definitive discontinuation of the treatment during the first 12 weeks $(+/-2$ weeks depending on real clinical practice) of treatment (Table S5).

The only agreement extension signed in 2017 corresponds to a one-year prolongation of the convention signed in April 2016 between a pharmaceutical company and CatSalut for the use of cetuximab in the first line of treatment in metastatic colorectal cancer (Table 2) [31].

Finally, one RSA was signed in 2018 between a pharmaceutical company and CatSalut for the use of tolvaptan in patients with rapidly progressive autosomal dominant polycystic kidney disease (ADPKD) [32]. In this case, the payment scheme will be based on an annual expenditure ceiling for treatments with 
tolvaptan (Table 4). Once the annual expenditure ceiling established for each calendar year has been reached, the pharmaceutical company will assume the cost of treatment with tolvaptan that exceeds this ceiling.

In a more descriptive way, we have identified 5 agreements within the scope of oncology diseases, which encompass $57.1 \%$ of the studied agreements. These reports refer to colorectal, melanoma, HER2+ breast cancer and non-small cell lung cancer.

In general, PLR schemes analyzed have a validity period of 1 year, with the possibility to extend the agreement annually up to a maximum of 4 years, including the original agreement period. There are some agreements with a larger validity period, as the agreement regarding multiple sclerosis with a validity period of 2 years, and the RSA related to ADPKD with a validity period of 3 years. Both agreements can also be expanded up to a maximum of 4 years. As expected, following the same norm, both agreement extensions are active over a period of 12 months (Table 4).

Inclusion criteria and clinically relevant result evidence include biochemical tests, imaging, disease morphology, physical and mobility tests, functional state, scoring and descriptive criteria. These are studied according to the disease and treatment of interest. In some cases, such as the signed agreement regarding pertuzumab + trastuzumab or panitumumab + folfox inclusion criteria are very similar to the inclusion criteria of clinical trials concerning the same drugs. Rather, other agreements include very ambiguous inclusion and exclusion criteria or less specific descriptions.

Regarding time to clinical results or outcome measurements, it varies across agreements. Whilst some measurements are obtained as soon as 2 weeks after treatment initiation, others are evaluated 5 to 6 months later. Four of the reports $[24,26,27,30]$ indicate evaluation should be reported within 12 weeks of the start of the treatment, one of them being described in relation to treatment cycles.

Finally, drug price for reimbursement were not broadly specified in most agreements, which simply stated that the price is associated to ex-factory price plus value added tax (VAT) with a $7.5 \%$ discount (RD 08/2010). Only three of the MEA indicate the exact price of drugs including: fampridine, panitumumab and the expenditure ceiling established for tolvaptan. 


\section{DISCUSSION}

These results are in accordance with an international review describing PLRs as, currently, the most common MEA having overtaken coverage with evidence development agreements since 2012. Most reviewed publications agree also with the areas of disease related to such MEA taking into account that $41 \%$ of reports concerned oncology drugs and $8 \%$ rheumatology treatments $[3,15]$.

Even though the information is limited the trend line suggests that older agreements (i.e. 2013) were signed with individual hospitals whereas more recent MEA were signed with CatSalut, which implies the agreement implementation in the entire public healthcare system in Catalonia (SISCAT). Although in most cases we cannot know what ensued after the initial agreement, this suggests success of the first scheme implementations. Such assumption is supported by the fact that many interviewed healthcare professionals in Spain and European pharmaceutical decision makers and stakeholders, expect MEA to increase in the future, in particular PLRs [33]. The main reasons are the greater reduction in total cost and the increase in uncertainty management that these agreements provide [34]. Although global trends have varied over time and seem to be back on the rise after a slowdown in 2013-2014, the number of RSAs in the UK has decreased, opting more often for confidential discounts [15].

However, partly attributed to the inconsistent published reports and the difficulties that arise from controlling outcomes in real-world environments, there are hardly any studies regarding the impact of RSA postimplementation, a field of great relevance regarding health policies, which is also an issue in other regions $[2,35,36]$.

On a general note, and based on the agreements included in this study, a variety of pharmaceutical companies have been involved in signing MEA for innovative drugs, contributing to new marked access schemes in Catalonia.

Regarding the validity period of MEA, Central and Eastern European countries share similar validity periods ranging from 1 to 5 years, 2 years being the average length [3].

Regarding limitations of this study, we cannot know whether there has been an increase in MEA in Catalonia or not, because not all MEA were public we cannot know the number or characteristics of non-published 
agreements. The studied reports correspond to those publicly accessible during July 2018 , however a more rigorous analysis could be developed if all MEA were published and recollected. In addition, information about what ensued after the initial agreement was unavailable. In future research we might contact different stakeholders to hear about their assessment of these MEAs in order to obtain unavailable information.

\section{CONCLUSION}

MEA are gaining interest internationally amongst stakeholders, pharmaceutical companies and national healthcare centers, particularly RSA and PLRs. This trend is also observed in the Spanish region of Catalonia where a significant growth in patient access schemes mostly regarding oncology treatments is observable since 2011 when the first payment-by-results agreement was signed in regards to metastatic non-small cell lung cancer. However, partly attributed to the inconsistent published reports and the difficulties that arise from controlling outcomes in real-world environments, there are hardly any studies regarding the impact of RSA post-implementation, a field of great relevance regarding health policies, which is also an issue in other regions.

\section{DISCLOSURE}

Funding: there is no sponsorship/funding.

Financial relationship: there are no relationships to be declared.

Author Contributions: JD was involved in the design of this study and has reviewed the draft of the paper critically for intellectual content. MA was involved in the analysis and interpretation of the data and in the drafting of the paper. All the authors have approved the final version of the manuscript to be published. 
Table 1 Managed entry agreements signed in Catalonia in 2013

Report date May 2013

Agreement type Performance-linked reimbursement

$\begin{aligned} & \text { Agreement } \\ & \text { length }\end{aligned}$
1 year (can be renewed annually)

Drug name $\quad$ CIMZIA $\AA$

Active
ingredient $\quad$ Certolizumab pegol

\section{Pharmaceutical company UCB Pharma S.A.}

Indication Rheumatoid arthritis

RA patients naive to biological drug therapy

Inclusion criteria

- ACR 2010 criteria

- Inadequate response to FAMM (including methotrexate)

- Availability for efficacy evaluation (clinical response) at week 12

\section{Time to} response Week 12

evaluation

Patient classification by response
Good response:

- $\quad$ DAS-28 $<2.6$ and $<3.2$ in terms of remission or low activity

- For evolved disease: $3.2<$ DAS- $28<5.1$ (when the reduction is significant)

\section{Economic conditions \\ Ex-factory price + VAT $+7.5 \%$ disc.}

Reimbursement Trimestral restocking of the drug supplies used by patients up to week 12 if optimal clinical response hasn't been reached

Institution Bellvitge University Hospital (Catalonia)

Reference

ACR American college of Rheumatology, DAS-28 Disease Activity Score 28, VAT value added tax 
Table 2 Analyzed agreement extensions in Catalonia

\begin{tabular}{|c|c|c|c|c|c|c|c|c|}
\hline $\begin{array}{l}\text { Original } \\
\text { report } \\
\text { date }\end{array}$ & Extension & $\begin{array}{l}\text { Agreement } \\
\text { type }\end{array}$ & $\begin{array}{l}\text { Agreement } \\
\text { length }\end{array}$ & Drug name & $\begin{array}{l}\text { Active } \\
\text { ingredient }\end{array}$ & $\begin{array}{l}\text { Pharmaceutical } \\
\text { company }\end{array}$ & Indication & Reference \\
\hline Jul-11 & Jul-13 & RSA & 1 year & IRESSA® & Gefitinib & $\begin{array}{l}\text { AstraZeneca } \\
\text { Farmacéutica } \\
\text { Spain S.A. }\end{array}$ & $\begin{array}{l}\text { Metastatic } \\
\text { non-small } \\
\text { cell lung } \\
\text { cancer }\end{array}$ & $(25)$ \\
\hline Apr-16 & Apr-17 & PLR & 1 year & ERBITUX® & Cetuximab & Merck S.L.U. & $\begin{array}{l}\text { Colorectal } \\
\text { metastatic } \\
\text { cancer }\end{array}$ & (31) \\
\hline
\end{tabular}

PLR Performance-linked reimbursement, RSA Risk-sharing agreement 
Table 3 Summary of managed entry agreements signed in Catalonia in 2017

\begin{tabular}{|c|c|c|c|c|c|c|c|c|}
\hline $\begin{array}{l}\text { Report } \\
\text { date }\end{array}$ & $\begin{array}{l}\text { Agreement } \\
\text { type }\end{array}$ & $\begin{array}{l}\text { Agreement } \\
\text { length }\end{array}$ & Drug name & $\begin{array}{l}\text { Active } \\
\text { ingredient }\end{array}$ & $\begin{array}{l}\text { Pharmaceutical } \\
\text { company }\end{array}$ & Indication & Institution & Reference \\
\hline Mar-17 & PLR & 1 year & $\begin{array}{l}\text { VECTIBIX® + } \\
\text { FOLFOX® }\end{array}$ & $\begin{array}{l}\text { Panitmumab + } \\
\text { fluorouracil, } \\
\text { leucovorin, } \\
\text { oxaliplatin }\end{array}$ & AMGEN S.A. & $\begin{array}{l}\text { First line treatment } \\
\text { for adult patients with } \\
\text { colorectal metastatic } \\
\text { cancer with wild type } \\
\text { RAS }\end{array}$ & CatSalut & $(26)$ \\
\hline Mar-17 & PLR & 1 year & KEYTRUDA® & Pembrolizumab & $\begin{array}{l}\text { Merck Sharp \& } \\
\text { Dohme de } \\
\text { España S.A. }\end{array}$ & $\begin{array}{l}\text { Advanced } \\
\text { unresectable } \\
\text { metastatic } \\
\text { melanoma }\end{array}$ & CatSalut & $(27)$ \\
\hline Mar-17 & PLR & 2 years & FAMPYRA® & Fampridine & $\begin{array}{l}\text { Biogen Spain } \\
\text { S.L. }\end{array}$ & $\begin{array}{l}\text { Multiple sclerosis } \\
\text { with motor disability }\end{array}$ & CatSalut & $(28)$ \\
\hline May-17 & PLR & 1 year & $\begin{array}{l}\text { PERJETA® + } \\
\text { HERCEPTIN® }\end{array}$ & $\begin{array}{l}\text { Pertuzumab } \\
\text { trastuzumab }\end{array}$ & $\begin{array}{l}\text { Roche } \\
\text { S.A. }\end{array}$ & $\begin{array}{l}\text { Neaoadjuvant } \\
\text { treatment of HER2+ } \\
\text { locally advanced, } \\
\text { inflamatory or early } \\
\text { stage with a high } \\
\text { relapse risk breast } \\
\text { cancer } \\
\text { combination with } \\
\text { chemotherapy }\end{array}$ & CatSalut & (29) \\
\hline Jun-17 & PLR & 1 year & $\begin{array}{l}\text { MEKINIST® + } \\
\text { TAFINLAR® }\end{array}$ & $\begin{array}{l}\text { Trametinib } \\
\text { dabrafenib }\end{array}$ & $\begin{array}{l}\text { Novartis } \\
\text { Farmacéutica } \\
\text { S.A. }\end{array}$ & $\begin{array}{l}\text { Advanced } \\
\text { unresectable } \\
\text { metastatic } \\
\text { melanoma with } \\
\text { BRAF V600 mutation }\end{array}$ & CatSalut & (30) \\
\hline
\end{tabular}


Table 4 Managed entry agreements signed in Catalonia in 2018

\begin{tabular}{ll} 
Report date & April 2018 \\
\hline $\begin{array}{l}\text { Agreement } \\
\text { type }\end{array}$ & Risk sharing agreement \\
\hline
\end{tabular}

Agreement 3 years (can be renewed annually up to a maximum of 4 years)
length

\begin{tabular}{ll}
\hline Drug name & JINARC® \\
\hline $\begin{array}{l}\text { Active } \\
\text { ingredient }\end{array}$ & Tolvaptan \\
\hline
\end{tabular}

\section{Pharmaceutical company Otsuka Pharmaceutical S.A.}

Indication Rapidly progressing autosomal dominant polycystic kidney disease (ADPKD)

Inclusion criteria

- 50 years or less

- Stage 1-3a chronical kidney disease:

- 18-30 years: stage $1-3 a\left(\right.$ eGFR $\left.>45 \mathrm{ml} / \mathrm{min} / 1.73 \mathrm{~m}^{2}\right)$

- 30-40 years: stage $2-3 a\left(e G F R=45-90 \mathrm{ml} / \mathrm{min} / 1.73 \mathrm{~m}^{2}\right)$

- 40-50 years: stage $3 a\left(\right.$ eGFR $\left.=45-60 \mathrm{ml} / \mathrm{min} / 1.73 \mathrm{~m}^{2}\right)$

- Rapid progressions:

○ Decrease of eGFR $>5 \mathrm{ml} / \mathrm{min} / 1,73 \mathrm{~m}^{2}$ in a year and/or $>2.5$ $\mathrm{ml} / \mathrm{min} / 1,73 \mathrm{~m}^{2}$ during 5 years (CKD-EPI)

- Annual increase of total kidney volume $>5 \%$ measured with NMR at least 3 times (with 6 months between measurements)

$\circ$ In absence of the above tests, groups 1D \& 1E using the Mayo clinic predictive model

\begin{tabular}{ll} 
& Annual expenditure ceiling [Ex-factory price + VAT $+7.5 \%$ disc.]: \\
& 2018: $6,790,952 €$ \\
Economic & 2019: $1,346,828 €$ \\
conditions & 2020: $1,660,652 €$ \\
& $\begin{array}{l}\text { The pharmaceutical company will assume the cost of the treatment that exceeds the } \\
\text { expenditure ceiling }\end{array}$ \\
\hline Institution & CatSalut \\
\hline
\end{tabular}

\section{Reference}




\section{REFERENCES}

1. CatSalut. Guía para la definición de criterios de aplicación de esquemas de pago basados en resultados (EPR) en el ámbito farmacoterapéutico (Acuerdos de Riesgo Compartido). Barcelona: Generalitat de Catalunya, Departamento de Salut; 2014.

${ }^{* \star}$ It is the guide that defines the criteria to apply managed entry agreements in Catalonia.

2. Clopes A, Gasol M, Cajal R, et al. Financial consequences of a payment-by-results scheme in Catalonia: gefitinib in advanced EGFR-mutation positive non-small-cell lung cancer. J Med Econ. 20(1), 1-7 (2017).

${ }^{*}$ First results of the applied payment-by-results scheme in Catalonia.

3. Ferrario A, Arãja D, Bochenek T, et al. The Implementation of Managed Entry Agreements in Central and Eastern Europe: Findings and Implications. Pharmacoeconomics. 35(12), 127185 (2017).

4. Adamski J, Godman B, Ofierska-Sujkowska G, et al. Risk sharing arrangements for pharmaceuticals: potential considerations and recommendations for European payers. BMC Health Serv Res.10,153 (2010).

5. Gasol-Boncompte M, Mora-Ripoll R, Gilabert-Perramon A. Experiencias en acuerdos de riesgo compartido y esquemas de pago basados en resultados en Cataluña. [Online].; 2015 [cited 2018 July]. Available from: http://catsalut.gencat.cat/web/.content/minisite/catsalut/proveidors_professionals/medicame nts_farmacia/acords_risc_compartit/AES-2015_poster_68_ARC_def_09_06_2015.pdf. **Poster presentation of the previous experience with risk-sharing agreements and payment schemes based on results in Catalonia.

6. Garrison LP, Towse A, Briggs A, et al. Performance-Based Risk-Sharing ArrangementsGood Practices for Design, Implementation, and Evaluation: Report of the ISPOR Good 
Practices for Performance-Based Risk-Sharing Arrangements Task Force. Value Health. 16(5), 703-19 (2013).

7. Nazareth T, Ko J, Sasane R, et al. Outcomes-Based Contracting Experience: Research Findings from U.S. and European Stakeholders. J Manag Care Spec Pharm. 23(10), 1018-26 (2017).

8. Kelly RJ, Smith TJ. Delivering maximum clinical benefit at an affordable price: engaging stakeholders in cancer care. Lancet Oncol.15(3),e112-8 (2014).

9. Howard DH, Bach PB, Berndt ER, Conti RM. Pricing in the Market for Anticancer Drugs. J Econ Perspect. 29(1),139-62 (2015).

10. Kantarjian HM, Fojo T, Mathisen M, Zwelling LA. Cancer drugs in the United States: Justum Pretium--the just price. J Clin Oncol. 31(28), 3600-4 (2013).

11. Cohen D. Cancer drugs: high price, uncertain value. BMJ. 359, j4543 (2017).

12. Patent expiry and costs for anticancer medicines for clinical use. Generics Biosimilars Initiat J. 6(3), 105-6 (2017).

13. Hill A, Gotham D, Fortunak J, et al. Target prices for mass production of tyrosine kinase inhibitors for global cancer treatment. BMJ open. 6(1), e009586 (2016).

14. Hill A, Redd C, Gotham D, Erbacher I, Meldrum J, Harada R. Estimated generic prices of cancer medicines deemed cost-ineffective in England: a cost estimation analysis. BMJ open. 7(1), e011965 (2017).

15. Carlson J, Chen S, Garrison LP. Performance-Based Risk-Sharing Arrangements: An Updated International Review. Pharmacoeconomics. 35(10), 1063-72 (2017).

16. Ferrario A, Kanavos P. Dealing with uncertainty and high prices of new medicines: a comparative analysis of the use of managed entry agreements in Belgium, England, the Netherlands and Sweden. Soc Sci Med. 124, 39-47 (2015). 
17. Goble J, Ung B, van Boemmel-Wegmann S, Navarro RP, Parece A. Performance-Based RiskSharing Arrangements: U.S. Payer Experience. J Manag Care Spec Pharm. 23(10), 1042-52 (2017).

18. Yu J, Chin L, Oh J, Farias J. Performance-Based Risk-Sharing Arrangements for Pharmaceutical Products in the United States: A Systematic Review. J Manag Care Spec Pharm. 23(10), 1028-40 (2017).

19. Brown D, Sheer RB, Pasquale $M$, et al. Payer and Pharmaceutical Manufacturer Considerations for Outcomes-Based Agreements in the United States. Value Health. 21(1), 33-40 (2018).

20. Maskineh C, Nasser S. Managed Entry Agreements for Pharmaceutical Products in Middle East and North African countries: Payer and Manufacturer Experience and Outlook. Value Health Reg Issues. 16, 33-8 (2018).

21. Piatkiewicz T, Traulsen J, Holm-Larsen. Risk-Sharing Agreements in the EU: A Systematic Review of Major Trends. Pharmacoecon Open. 2(2), 109-23 (2018).

22. Ferrario A, Kanavos P. Managed entry agreements for pharmaceuticals: the European experience. London: The London School of Economics and Political Science. EMiNet, Brussels, Belgium (2013).

23. CatSalut. Catsalut web page. [Online].; 2018 [cited 2018 July]. Available from: http://catsalut.gencat.cat/ca/coneix-catsalut/convenis-contractes/convenis/

24. CatSalut. Conveni subscrit en data 13 de maig de 2013, entre el laboratori farmacèutic UCB PHARMA, SA, l'Hospital Universitari de Bellvitge i el Servei Català de la Salut, model de risc compartit en el cost, d'administració del medicament CIMZIA®. [Online].; 2013 [cited 2018 July]. Available from: http://catsalut.gencat.cat/web/.content/minisite/catsalut/coneix_catsalut/convenis_contractes /convenis/2013/1482_13.pdf. 
25. CatSalut. Conveni AstraZeneca i CatSalut per a la pròrroga del model de risc compratit del cost d'inhibidors de la proteïna quinasa en pacients amb càncer de pulmó metastàtic no microcític. [Online]; 2013 [cited 2018 July]. Available from: http://catsalut.gencat.cat/web/.content/minisite/catsalut/coneix_catsalut/convenis_contractes /convenis/2013/1484_13.pdf.

26. CatSalut. Conveni marc de pagament per resultats de Vectibix en el tractament de pacients adults amb carcinoma colorrectal metastàtic (CCRM) amb ras no mutat (wild-type) en primera línia en combinació amb Folfox entre CatSalut i Amgen SA. [Online].; 2017 [cited 2018 July]. Available from: http://catsalut.gencat.cat/web/.content/minisite/catsalut/coneix_catsalut/convenis_contractes /convenis/2017/1628-17.pdf.

27. CatSalut. Conveni marc de risc compartit i de pagament per resultats de Keytruda (Pembrolizumab) en el tractament de melanoma avançat (Irressecable o metastàtic) entre el CatSalut i Merck Sharp \& Dohme de España, SA (MSD). [Online].; 2017 [cited 2018 July]. Available from: http://catsalut.gencat.cat/web/.content/minisite/catsalut/coneix_catsalut/convenis_contractes /convenis/2017/1629-17.pdf.

28. CatSalut. Conveni marc de pagament per resultats de Fampridina per la millora de la marxa en pacients amb esclerosi múltiple amb discapacitat de la marxa entre el CatSalut i Biogen Spain, S.L. [Online].; 2017 [cited 2018 July]. Available from: http://catsalut.gencat.cat/web/.content/minisite/catsalut/coneix_catsalut/convenis_contractes /convenis/2017/1631-17.pdf.

29. CatSalut. Conveni marc de pagament per resultats de Perjeta (pertuzumab) en combinació amb Herceptin en el tractament neoadjuvant del càncer de mama HER2-positiu, entre el CatSalut i Roche Farma, SA. [Online].; 2017 [cited 2018 July]. Available from: 
http://catsalut.gencat.cat/web/.content/minisite/catsalut/coneix_catsalut/convenis_contractes /convenis/2017/1644-17.pdf.

30. CatSalut. Conveni marc de pagament per resultats de Mekinist en combinació amb Tafinlar indicat pel tractament del pacients adults amb melanoma no ressecable o metastàtic amb mutació BRAF V600 entre el CatSalut i Novartis Farmacéutica, S.A. [Online].; 2017 [cited 2018 July]. Available from: http://catsalut.gencat.cat/web/.content/minisite/catsalut/coneix_catsalut/convenis_contractes /convenis/2017/1645-17.pdf.

31. CatSalut. Adenda al conveni de pagament per resultats de cetuximab en primera línia càncer colorectal metastàtic entre CatSalut i Merck subscrit entre el CatSalut i Merck, SLU en data 5 d'abril de 2016. [Online].; 2017 [cited 2018 July]. Available from: http://catsalut.gencat.cat/web/.content/minisite/catsalut/coneix_catsalut/convenis_contractes /convenis/2017/1638-17.pdf.

32. CatSalut. Conveni marc regulador d'un acord de risc compartit basat en resultats financers de tolvaptan (Jinarc), per a poliquístosis renal autosòmica dominant (PQRAD) de ràpida progressió entre CatSalut i Otsuka Pharmaceutical, SA. [Online].; 2018 [cited 2018 July]. Available from: http://catsalut.gencat.cat/web/.content/minisite/catsalut/coneix_catsalut/convenis_contractes /convenis/2018/1676-18.pdf.

33. Rojas García P, Antoñanzas Villar F. Los contratos de riesgo compartido en el sistema nacional de salud: percepciones de los professionales sanitarios. [Risk sharing contracts in the national health care system: Perceptions of health care professionals]. (Spanish). Rev Esp Salud Publica. 92(4). e20 (2018).

*Perceptions of healthcare professionals about the risk sharing agreements. 
34. Dunlop WC, Staufer A, Levy P, Edwards GJ. Innovative pharmaceutical pricing agreements in five European markets: A survey of stakeholder attitudes and experience. Health Policy. 122 (5), 528-32 (2018).

35. Garattini L, Curto A, van de Vooren K. Italian risk-sharing agreements on drugs: are they worthwhile? Eur J Health Econ. 16(1), 1-3 (2015).

36. Garattini L, Curto A. Performance-Based Agreements in Italy: 'Trendy Outcomes' or Mere Illusions?. Pharmacoeconomics. 34(10), 967-69 (2016). 


\section{SUPPLEMENTARY INFORMATION}

Table S1 Managed entry agreements signed in Catalonia in 2017 (VECTIBIX ${ }^{\circledR}+$ FOLFOX $^{\circledR}$ )

\begin{tabular}{ll} 
Report date & Mar-17 \\
\hline Agreement type & Performance-linked reimbursement \\
\hline Agreement length & 1 year (can be renewed annually up to a maximum of 4 years) \\
\hline Drug name & VECTIBIX $^{\circledR}+$ FOLFOX $^{\circledR}$ \\
\hline Active ingredient & Panitumumab + fluorouracil, leucovorin, oxaliplatin \\
\hline $\begin{array}{l}\text { Pharmaceutical } \\
\text { company }\end{array}$ & AMGEN S.A. \\
\hline Indication &
\end{tabular}

Indication

First line treatment for adult patients with colorectal metastatic cancer with wild type RAS

\begin{tabular}{|c|c|}
\hline Inclusion criteria & $\begin{array}{ll}\text { - } & \geq 18 \text { year olds } \\
\text { - } & \text { Histological evidence of colorectal metastatic cancer } \\
\text { - } & \text { Wild type RAS (KRAS/NRAS) } \\
\text { - } & \text { First-line Folfox + panitumumab treatment } \\
\text { - } & \text { Disease measurable by RECIST } 1.1 \\
\text { - } & \text { Functional activity degree ECOG from 0-1 }\end{array}$ \\
\hline Exclusion criteria & $\begin{array}{l}\text { - Previous chemotherapy (or other treatment against colorectal metastatic cancer). } \\
\text { Except for adjuvant chemotherapy based on fluoroprimidines or oxaliplatin } \\
\text { dispensed at least } 6 \text { and } 12 \text { months prior to the start of the treatment, respectively } \\
\text { - } \quad \text { Previous treatment with anti-EGFR antibodies or small molecule EGFR inhibitors }\end{array}$ \\
\hline $\begin{array}{l}\text { Time to response } \\
\text { evaluation }\end{array}$ & $\begin{array}{lccccc}\text { Week } 12 & (+/-1) & \text { since } \quad \text { the } \quad \text { start } & \text { of } & \text { the } & \text { treatment } \\
\text { (measures at week } 10 \text { and } 14 \text { will also be considered valid) } & \end{array}$ \\
\hline $\begin{array}{l}\text { Response } \\
\text { evaluation criteria }\end{array}$ & $\begin{array}{ll}\text { - } & \text { RECIST criteria } \\
\text { - } & \text { Thorax, abdomen and pelvis CT scan } \\
\text { - } & \text { Radiology progression report } \\
\text { - } & \text { NMR (if used during the whole treatment) }\end{array}$ \\
\hline $\begin{array}{l}\text { Patient } \\
\text { classification by } \\
\text { response }\end{array}$ & $\begin{array}{l}\text { Non-responding patients: } \\
-\quad \text { Progression of the disease at week } 12(+/-1) \text { according to RECIST } 1.1 . \\
-\quad \text { Suspicious symptoms of progression before week } 12(+/-1) \text { are evaluated. } \\
-\quad \text { Treatment modifications previous to the } 12(+/-1) \text { week mark. } \\
-\quad \text { Tumor progression or secondary to adverse effects exitus. }\end{array}$ \\
\hline $\begin{array}{l}\text { Economic } \\
\text { conditions }\end{array}$ & $\begin{array}{l}\text { Vectibix }{ }^{\circledR}(400 \mathrm{mg}): 1,444.96 €(7.5 \% \text { disc }) . \\
\text { Vectibix }{ }^{\circledR}(100 \mathrm{mg}): 361.24 €(7.5 \% \text { disc })\end{array}$ \\
\hline Reimbursement & $\begin{array}{l}\text { Payment value or a quantity of vials equivalent to the total of consumed vials by non- } \\
\text { responding patients up to the time of evaluation ( } 12 \text { weeks) will be reimbursed to the } \\
\text { hospital. Exclusion: Change of treatment strategy prior to week } 12\end{array}$ \\
\hline Institution & Catsalut \\
\hline Reference & (26) \\
\hline
\end{tabular}


Table S2 Managed entry agreements signed in Catalonia in 2017 (KEYTRUDA ${ }^{\circledR}$ )

\begin{tabular}{|c|c|}
\hline Report date & Mar-17 \\
\hline Agreement type & Performance-linked reimbursement \\
\hline Agreement length & 1 year (can be renewed annually up to a maximum of 4 years) \\
\hline Drug name & KEYTRUDA $^{\circledR}$ \\
\hline Active ingredient & Pembrolizumab \\
\hline $\begin{array}{l}\text { Pharmaceutical } \\
\text { company }\end{array}$ & Merck Sharp \& Dohme de España S.A. \\
\hline Indication & Advanced unresectable metastatic melanoma \\
\hline Inclusion criteria & $\begin{array}{l}\text { Patients with advanced unresectable metastatic melanoma in a good functional state that } \\
\text { meet at least one of the following criteria: } \\
\text { - without BRAF mutation that haven't been treated previously } \\
\text { - +BRAF mutation with normal LDL levels and without clinically significant symptoms } \\
\text { of tumor progression that haven't been treated previously } \\
\text { +BRAF mutations that have been treated with +/-BRAF or MEK inhibitor, that are } \\
\text { candidates for second line treatment with pembrolizumab }\end{array}$ \\
\hline
\end{tabular}

\begin{tabular}{lrl}
\hline $\begin{array}{l}\text { Time to response } \\
\text { evaluation }\end{array}$ & 4 first cycles (12 weeks) \\
\hline Response & $\bullet$ & Weight \\
evaluation criteria & $\bullet$ & Disease stage \\
& $\bullet$ & Functional state according to ECOG \\
& $\bullet$ & HDL levels \\
\hline
\end{tabular}

Economic
conditions

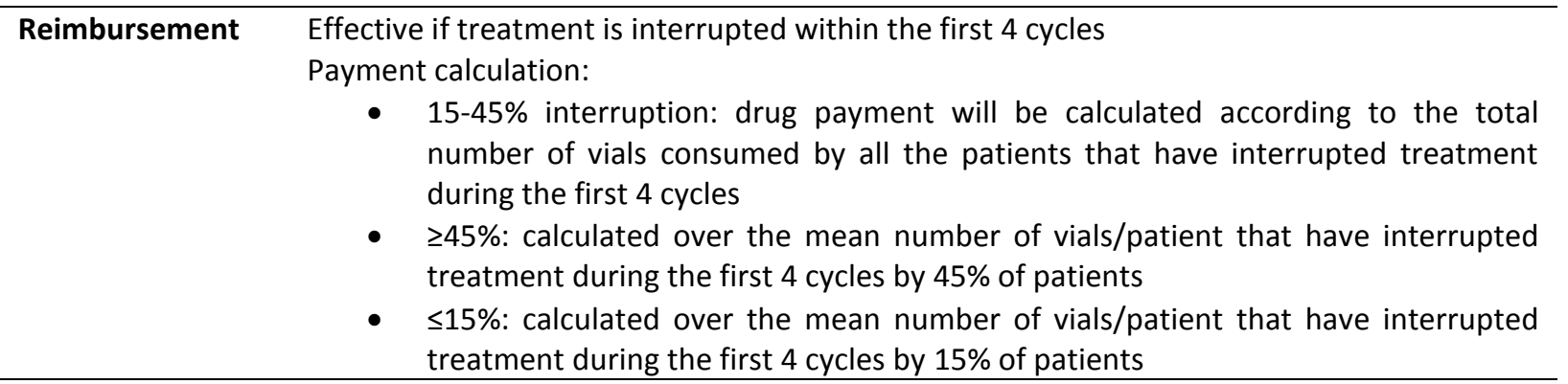

\begin{tabular}{ll}
\hline Institution & CatSalut \\
\hline Reference & (27)
\end{tabular}

ECOG Eastern Cooperative Oncology Group, LDL low density lipoprotein, $H D L$ high density lipoprotein 
Table S3 Managed entry agreements signed in Catalonia in 2017 (FAMPYRA ${ }^{\oplus}$ )

T25FW Timed 25-Foot Walk, 2MWT Two minute walk test, MSWS-12 scale multiple sclerosis walking scale

Report date Mar-17

\begin{tabular}{|c|c|}
\hline Agreement type & Performance-linked reimbursement \\
\hline Agreement length & 2 years (can be renewed annually up to a maximum of 4 years) \\
\hline Drug name & FAMPYRA $^{\circledR}$ \\
\hline Active ingredient & Fampridine \\
\hline $\begin{array}{l}\text { Pharmaceutical } \\
\text { company }\end{array}$ & Biogen Spain S.L. \\
\hline Indication & Multiple sclerosis with motor disability \\
\hline Inclusion criteria & $\begin{array}{l}\text { Patients with multiple sclerosis and motor disability that are susceptible to be treated with } \\
\text { fampridine }\end{array}$ \\
\hline $\begin{array}{l}\text { Time to response } \\
\text { evaluation }\end{array}$ & 2 weeks \\
\hline
\end{tabular}

\section{Response} evaluation criteria
- $\quad$ T25FW Improve walking velocity in $25 \%$

- $\quad 2$ MWT Improve in $25 \%$ (if the patient cannot take this test, $15 \%$ improvement for "up and go" test)

- 8 points improvement in the MSWS-12 scale

\begin{tabular}{ll}
\hline $\begin{array}{l}\text { Patient } \\
\text { classification } \begin{array}{l}\text { by } \\
\text { response }\end{array}\end{array}$ & $\begin{array}{l}\text { Pesponding patients: } \\
\text { Economic } \\
\text { conditions }\end{array}$ \\
& $\begin{array}{l}\text { Ex-factory price: } 192.31 € \\
+4 \% \text { VAT: } 185.00 €\end{array}$ \\
\hline Reimbursement $177.89 €$ \\
$\begin{array}{ll}\text { If response is not maintained after } 3 \text { months the pharmaceutical company will assume the } \\
\text { total cost of the 3-month treatment }\end{array}$ \\
\hline Institution & CatSalut \\
\hline Reference & (28)
\end{tabular}


Table S4 Managed entry agreements signed in Catalonia in 2017 (PERJETA ${ }^{\circledR}+$ HERCEPTIN $^{\circledR}$ )

\begin{tabular}{|c|c|}
\hline Report date & May-17 \\
\hline Agreement type & Performance-linked reimbursement \\
\hline Agreement length & 1 year (can be renewed annually up to a maximum of 4 years) \\
\hline Drug name & PERJETA $^{\circledR}+$ HERCEPTIN $^{\circledR}$ \\
\hline Active ingredient & Pertuzumab + trastuzumab \\
\hline $\begin{array}{l}\text { Pharmaceutical } \\
\text { company }\end{array}$ & Roche Farma S.A. \\
\hline Indication & $\begin{array}{l}\text { Neaoadjuvant treatment of locally advanced, inflammatory or early stage with a high relapse } \\
\text { risk HER2+ breast cancer in combination with chemotherapy }\end{array}$ \\
\hline Inclusion criteria & $\begin{array}{l}\text { - Patients with HER2+ tumors evidenced by IHC }+ \text { or FISH / CISH } \\
\text { - Locally advanced tumor, inflammatory or } \geq 2 \mathrm{~cm} \text { in diameter or axillary lymph node } \\
\text { affectation } \\
\text { - ECOG 0-1 }\end{array}$ \\
\hline
\end{tabular}

\section{Exclusion criteria}

- Patients with a cardiopathy that prevents them from using trastuzumab

- $\quad$ LVEF $\leq 50 \%$

- Patients with disease that isn't considered to have a high risk of relapse

\begin{tabular}{|c|c|}
\hline $\begin{array}{l}\text { Time to response } \\
\text { evaluation }\end{array}$ & Treatment duration (5-6 months) \\
\hline $\begin{array}{l}\text { Response } \\
\text { evaluation criteria }\end{array}$ & Complete pathological response (урт0 / is ypN0) in breast and armpit \\
\hline Reimbursement & $\begin{array}{l}\text { The pharmaceutical company will assume all cost only when patients do not achieve clinical } \\
\text { response (stable disease or progression according to RECIST criteria). } \\
\text { Packets of Herceptin IV or/and SC will be administered to the hospital according to an } \\
\text { equivalent cost of Perjeta }{ }^{\circledR} \text {. } \\
\text { Fractioned packages will be accumulated for return until the following period. }\end{array}$ \\
\hline Institution & CatSalut \\
\hline Reference & (29) \\
\hline
\end{tabular}


Table S5 Managed entry agreements signed in Catalonia in 2017 (MEKINIST ${ }^{\oplus}+$ TAFINLAR $^{\circledast}$ )

\begin{tabular}{|c|c|}
\hline Report date & Jun-17 \\
\hline Agreement type & Performance-linked reimbursement \\
\hline Agreement length & 1 year (can be renewed annually up to a maximum of 4 years) \\
\hline Drug name & MEKINIST $^{\circledR}+$ TAFINLAR $^{\circledR}$ \\
\hline Active ingredient & Trametinib + dabrafenib \\
\hline $\begin{array}{l}\text { Pharmaceutical } \\
\text { company }\end{array}$ & Novartis Farmacéutica S.A. \\
\hline Indication & Advanced unresectable metastatic melanoma with BRAF V600 mutation \\
\hline Inclusion criteria & $\begin{array}{l}\text { Advanced unresectable metastatic melanoma with no previous treatment } \\
\text { - } \quad \text { Confirmed BRAF V600 mutation } \\
\text { - } \quad \text { ECOG 0-1 (ECOG } 2 \text { if related to the disease symptomatology) }\end{array}$ \\
\hline
\end{tabular}

\section{Exclusion criteria}

- Patients in risk of retinal vein occlusion or central serous retinopathy

- Patients with uveal melanoma

- Patients with untreated active cerebral metastasis

- Patients treated with BRAF inhibitor

Time to response
evaluation $\quad 12$ weeks $(+/-2)$

\section{Response}

evaluation criteria

Radiologic test or RECIST 1.1 criteria

\begin{tabular}{ll}
\hline $\begin{array}{l}\text { Patient } \\
\text { classification } \\
\text { response }\end{array}$ & by \\
& $\begin{array}{l}\text { Non-responders: } \\
\text { Patient with definite discontinuation of treatment during the first } 12 \text { weeks due to disease } \\
\text { progression }\end{array}$
\end{tabular}

Economic
conditions $\quad$ Ex-factory price + VAT $(+7.5 \%$ disc.)

\section{Reimbursement}

Effective by semester if disease progresses and/or patient presents severe adverse effects and/or intolerance leading to treatment discontinuation before week 12

\begin{tabular}{ll}
\hline Institution & CatSalut \\
\hline Reference & $(30)$ \\
ECOG Eastern Cooperative Oncology Group, RECIST Response evaluation criteria in solid tumors, VAT value added tax
\end{tabular}

